\title{
Traveling Through the Boondocks, In and Out of Academic Hierarchy
}

\author{
By Terry Caesar
}

State University of New York Press, Albany, NY, 2000, 203 pp.

ISBN 0-7914-4659-X

\author{
Review by Penny Fripp Jones \\ Independent Scholar and Writer \\ Atlanta, GA
}

Before opening the cover, "Traveling through the Boondocks" suggests an uncommon theme. Demolished cars, deserted highways, and empty stairwells are not expected to portray the context of higher education, but this is the first of many unexpected contradictions. Authentic campus scenes played out by real characters resembles a farce unmatched by fiction, spotlighting participants entangled in an inescapable lifestyle. Wry humor renders a remorseful message digestible as first hand observations expose hierarchical circumstances that cement the academic condition of exclusion. From the volumes that have discussed and theorized unending lists of inequities, Terry Caesar is unique. Challenging an unwritten authority, the open dialogue sparks recognition among educators and in an unexpected twist of events invites revitalization of American higher education.

Educator hopefuls will be enlightened and with this account of covert activity that has an influence on lives and careers. With railing sarcasm a professor of American literature artfully develops personal encounters at Clarion University to expose constraints devised and maintained by upper level interests. Exceptional scholars summarily situated at second-rate universities are eager to compete as major participants, but Ivy League schools, along with a number others, have secured enduring status as the primary purveyors of knowledge. Exclusion is recognized in events that confront academics daily, and secondary status eliminates a level of participation that fosters faculty development in the noble sense of expected performance. Scholastic overseers hold the privilege of disseminating wisdom that immobilizes subordinates with bureaucratic power.

Reputations are solidly marked with boundaries that are fixed by political correctness to contest the existence of institutional distinctions, but in reality a second rate perception is contrived by a salient positioned hierarchy. Pragmatic differences are cited, but any respectful reference to the espoused teaching purpose loses meaning within a structure that systematically removes the rewards of achievement. Nowhere is this restriction more obvious than in the field of research. Production and acceptance, rather than the project's scholastic contribution are rewarded, and the opportunity for publication is confined by campus affiliation.

A personal account of departmental politics suggests a pattern that works to 
maintain the order. While Clarion purports to make employment selections based on scholarship, the witnessed process finds familiar and socially compatible acquaintances securing a place on campus. Caesar leaves no doubt that selections are based on strong departmental influences. Hiring for compatibility perpetuates consistent behavior and expectations that ward off any thought of alteration or innovation. On noted campuses chosen colleagues must exhibit real evidence of exemplary scholarship. The additions to and formation of departments offer an opportunity to bring contrast and stimulation. Compatible inclusions at Clarion limit invention, and communal satisfaction along with the security of tenure install a cybernetic system of complacency.

Academic forums invite the opportunity for participants with correct affiliations to illuminate large groups about academic injustice. When race, gender and class run dry, a myriad of considerations exist for theorizing academic inconsistency. Theory is the established design for maintaining issues without informing, much less providing a solution. An ideology can offer rhetoric that never identifies the source and has no claim towards resolution. What this style of presentation does allow is an endless conjecture of little pragmatic advantage to the unnamed subject. If a cure is found, the game is over, and who among the privileged wants to join the ranks back at the university. Conferences are held for affiliates to posit and hold the lines on debated topics.

Grants that permit travel options are controlled by nebulous sources. Requirements are not obvious, and the winning papers are never available to define expectations. Scholastic considerations are often not divulged, and creativity is assumed to eliminate competition. Practiced research directs the course for a particular knowledge that assists the habit of exclusion and arbitrary determinations from empowered sources have predictable outcomes based on names.

Caesar's account of observation reports takes the time to introduce delightfully creative products of his contempt for forced accountability. These required assessments of colleague performance play a conspicuously prominent role in encouraging class structure within the institution. An entertaining interlude among other educational imperatives, this chapter is well positioned in the middle of a book full of bitter commentary. Equally engaging are the author's suppositions on where results are filed and the uselessness of such endeavors.

In a chapter of contrast, humor is lost to a discussion of applying for positions. Caesar vividly describes the original baptism into academia as a series of repeated rejections after which applicants are reconciled to the job of seeking employment. The reception for one among hundreds does not mirror past hiring ease. Endless attempts to secure a position provoke little response and certainly no revelation for clarification or improvement. Ironically, muted replies are a result of legal mechanisms installed to prevent injustice in corporate dynamics that erase the hope of reinstating traditional familiarity. Without a voiced reason for unsuccessful employment, personal failure is often assumed, and a once distinct professional calling is lost to intense networking and resume improvement.

Discussion of theory evolves into an elaboration on student inadequacies in the classroom. An introduction to reasoning at Clarion University proved the futility of teaching advanced literature in a second-rate university. The top, he asserts, dictate rules 
that muddle literary understanding for an audience not intellectually prepared or inclined towards high scholarship. Exposure to politicized rhetoric offends a contingency of learners who refuse to partake of thoughtfulness specifically aimed at broadening current exposure. A scathing report on student ineptness mellows with a protectionist commentary suggesting the inappropriate nature of this learning for local purpose, but conspicuously skirts taking responsibility for teaching inadequacies.

The importance of understanding theory is a masked agenda within the text on sabbatical privilege. Time away is so far removed from the original intention that the reward has lost all meaning. Only the elite regime moves about so freely that the experience can be taken for granted, while any favor has been removed from the bottom sector.

Thoughts digress, and the text is abandoned to recognize a noble intention has been diverted. This ultimate experiential encounter mimics the academic condition. Caesar's purpose is conveyed and leads a call for change. The unspoken topic resounds in the mind of educators who know the real subject is "teaching," and Caesar's book is well worth a read. 